\title{
An integrated plant nutrition system (IPNS) for corn in the Mid-Atlantic USA
}

\author{
Jose Franco Da Cunha Leme Filho ${ }^{\mathrm{a}}$ (D), Wade E. Thomason ${ }^{\mathrm{a}}$, Gregory K. Evanylo ${ }^{\mathrm{a}}$, \\ Xunzhong Zhang ${ }^{a}$, Michael S. Strickland ${ }^{b}$, Bee K. Chim ${ }^{c}$, and Andre A. Diatta ${ }^{a}$ \\ ${ }^{a}$ School of Plant \& Environmental Sciences, Virginia Polytechnic Institute \& State University, Blacksburg, \\ VA, USA; ${ }^{b}$ Department of Soil and Water Systems, University of Idaho, Moscow, ID, USA; ' United States \\ Department of Agriculture - Agricultural Research Service, North Central Agriculture Research Laboratory, \\ Brookings, SD, USA
}

\begin{abstract}
Current trends in agriculture have moved toward more sustainable cultivation systems with higher efficiency of input use. A variety of materials, derived from different resources, can serve as a crop nutrient sources. An Integrated Plant Nutrition System (IPNS) uses the combined and harmonious use of inorganic, organic and biological nutrient resources to maximize efficiency of inputs. We evaluated the effects of commercial nitrogen (N) fertilizer, humic acid compounds (HA), compost/manure teas and bioinoculants as inorganic, organic and biological resources, respectively and their synergy over three years on corn (Zea mays L.) in the Mid-Atlantic USA. The individual and combined application of HA and biofertilizer following the IPNS influenced corn height and leaf greenness to varying degrees, most likely due to biostimulant effects. In 2017, corn height, NDVl, greenness and vigor responded positively to biostimulant application to varying magnitudes and growth stages, however grain yield and nutrient content were not affected. In combined studies from 2018 and 2019 corn height was not impacted by biostimulant application but NDVI, photosynthetic efficiency, greenness and vigor were increased at different doses and corn growth stages. The combined use of $\mathrm{HA}+$ biofertilizer (Microlife Humic + Microgeo) was the only treatment leading to increased grain yield. This study demonstrates that the individual and combined application of $\mathrm{HA}$ and biofertilizer can influence corn growth and vigor at various points during the growing season. However, the current study cannot conclusively confirm that the integrated use of HA and biofertilizers (IPNS) is a better practice than the application of each compound individually.
\end{abstract}

\section{ARTICLE HISTORY}

Received 26 May 2020

Accepted 12 August 2020

\section{KEYWORDS}

biofertilizer; biostimulant; compost tea; corn; humates; humic acid; manure tea

\section{Introduction}

To date, most agricultural research has prioritized yield increases at the expense of crop quality or optimization of resources (Bulgari et al. 2015). However, current trends in agriculture have moved toward more sustainable cultivation systems with higher efficiency of input use, since mineral nutrient losses due to runoff, leaching, erosion and gas emissions are leading to environmental degradation (Adesemoye and Kloepper 2009; Bhattacharjee, Singh, and Mukhopadhyay 2008; Tilman 1998). Moreover, the excessive use of chemical fertilizer can decrease soil fertility and some agricultural systems are approaching theoretical maximum yield, where further fertilizer 
input does not result in increased yield (Ahmed 1995). Besides approaching theoretical maximum yield and negative environmental impacts, the three macronutrients nitrogen $(\mathrm{N})$, phosphorus $(\mathrm{P})$ and potassium $(\mathrm{K})$ are produced by the utilization of limited resources such as mining or fossil fuel consumption and the growing world population is increasing the total use of fertilizers as a consequence of higher demand for food (Frink, Waggoner, and Ausubel 1999; Vitousek et al. 1997). This pressure on limited resources necessitates the promotion of practices that maximize fertilizer efficiency and the scientific community is increasingly focused on this topic. According to Adesemoye and Kloepper (2009) just as research in the last century focused on reducing the use of pesticides, this century will be target ways to decrease the use of fertilizers.

A huge variety of materials can serve as a crop nutrient sources and they can be derived from inorganic, organic and biological reserves. Thereby, the atmospheric deposition, biological activity, plants residues, organic manure, urban waste and synthetic fertilizer are potential ways to enlarge the natural nutrients reserves already occurring in the soil. (Aulakh and Grant 2008). According to the Food and Agriculture Organization of the United Nations (FAO) (Shand 2007), the definition of an Integrated Plant Nutrition System (IPNS) is "the adaptation of the plant nutrition and soil fertility management in farming systems to site characteristics, taking advantage of the combined and harmonious use of inorganic, organic and biological nutrient resources to serve the concurrent needs of food production and economic, environmental and social viability." An IPNS requires an understanding of nutrient dynamics throughout the soil-microbe-plant system as nutrient availability is interconnected and can address issues ranging from nutrient excess to nutrient depletion and (Aulakh and Grant 2008).

The IPNS is a broad term, thus the combined practices need to explore the effects of different resources (Snapp, Mafongoya, and Waddington 1998). Under the category of inorganic, organic and biological there are many products or compounds and consequently the synergy of these products can vary depending on the strategy of the producer. According to the IPNS definition, the most effective use of the prescribed compounds used in an integrated manner will depend on their efficacy in a specific environment and local production systems (Aulakh and Grant 2008). The diversity of compounds and the potential negative or positive interaction of them in a particular ecosystem dictates the need for local research when developing the IPNS. Chemical or inorganic inputs can often be used more efficiently when combined with a proper organic/biological source (Adesemoye, Torbert, and Kloepper 2008). Thus, the challenge is to find the most appropriate combinations of organic and biological resources that result in positive synergy with inorganic fertilizers in the IPNS.

Humic acid (HA) is a heterogeneous and stable organic complex formed naturally in soils with the capability to give soil structure, porosity, water holding capacity, cation and anion exchange, and be part of the chelation of mineral elements (Pettit 2004). Moreover, the hormonelike activity present in HA can maximize plant nutrition along with the soil chelation function and increase plant growth (Vaughan and Malcolm 1985). Hence, the soil and plant effects can be intercorrelated and complementary, for instance, the plant root growth stimulation and the soil cation exchange capacity can be enhanced by HA (Chen and Aviad 1990). In other words, greater root area (Baldotto and Baldotto 2014) and nutrient accessibility (Chang et al. 2012) can stimulate plant development. Other parameters such as improved fruit quality and increased berry size in table grapes [Vitis Vinifera (L)], were reported as a beneficial result of HA application (Ferrara and Brunetti 2010).

Biofertilizers or bioinoculants are defined as substances derived from biological resources containing living microorganisms and used to maximize the uptake of inorganic nutrients and stimulate vegetative development by colonizing the interior of plants or the rhizosphere (Vessey 2003). They can be applied to seed, plant surfaces and soil (Sahu, Priyadarshani, and Rath 2012). The integrated use of these different biological compounds have shown to be promising in the functions mentioned in the definition above (Barea, Toro, and Azcón 2007; Hodge, Campbell, and 
Fitter 2001) plus to support the health of plants (Weller 2007). They can be used to decrease the deleterious impacts of chemical fertilizers (Bashan 1998). According to Goel et al. (1999) nitrogen fixing, phosphate solubilizing and plant growth promoting microorganisms exist in the biofertilizer category. Thus, the application of one or more beneficial bacteria and/or fungi has positively affected plant growth, yield and yield components on corn (Zea Mays L.) (Zarabi et al. 2011; Yosefi et al. 2011) and common beans (Vicia faba L.) (El-Habbasha, Hozayn, and Khalafallah 2007). Furthermore, biofertilizer products developed from compost tea enhanced vegetative growth of corn, soybean (Glycine Max L.) and lettuce (Lactuca sativa L.), possibly by improving nutrient uptake (Kim et al. 2015).

Humic acid and biofertilizers belong to a broader category of biostimulants due the fact that they are substances and microorganisms that enhance plant growth, however this categorization is still evolving (Calvo, Nelson, and Kloepper 2014). Canellas and Olivares (2014) exposed the basic mechanisms and benefits of the integrated use of these two biostmulants on many crops. However the actions of microorganisms applied as biofertilizers in a heterogeneous soil can be complex due to the existence of competitors and predators inhabiting the same environment (Young et al. 2006). Since HA is a major part of soil organic matter (SOM) and influences soil properties, HA might support the acclimation of inoculated microorganisms from the biofertilizer application (Canellas et al. 2013). The HA influence on root growth and architecture (Nardi, Concheri, and Dell'Agnola 1996) may favor the interaction between microbes and roots. Furthermore, the addition of HA is known to induce changes in the the structure of soil microbial communities in the rhizosphere of corn (Puglisi et al. 2009).

A thorough understanding of plant-microbial associations is crucial to boost the efficacy of plant nutrient uptake (Peoples and Craswell 1992; Zhu et al. 2001) However, little work has been done regarding crop response to the combined effect of HA and biofertilizers (Rose et al. 2014) and we hypothesize that the synergetic effects of HA + biofertilizers can improve corn development. This research assessed the effects of the integrated and individual use of HA and compost/ manure teas and bioinoculants along with inorganic fertilizer on corn growth, vigor and yield, compared to a control receiving only inorganic fertilizer.

\section{Materials and methods}

\section{Design of experiments and management}

Experiments in Virginia were conducted in 2017-2019 at Kentland Farm in Blacksburg and in 2018 near Champlain, VA. Experiments were planted into soybean residue at Champlain and into corn stover in all years at Blacksburg with direct seeding methods. Five biostimulant products (including organic and biological resources) were tested in this study. The organic products were Monty's and MicroLife Humic Acid Complex®; and the biological products were SoilSoup $\AA$, Microgeo ${ }^{\circledR}$ and Microgro Supreme Bioinoculant ${ }^{\circledR}$. The humic category was represented by Monty's ${ }^{\circledR}$ and MicroLife Humic Acid Complex ${ }^{\circledR}$ which was constituted of $2 \%$ humic acid/1\% organic carbon and $15 \%$ humic acid/1\% fulvic acid, respectively. One of the three biological fertilizers was Microgeo ${ }^{\circledR}$ which is a Brazilian patented product categorized as a manure tea. This biofertilizer is composed of organic compounds, active and dormant cells from various microorganisms (bacteria, yeasts, filamentous fungi, and algae), metabolites and organo-mineral chelates and it is produced through continuous anaerobic fermentation in a liquid media (D’Andrea 2002). According to the technical manual, the preparation is using the CLC® (Continuous Liquid Composting) process, where 5\% of the commercial biological fertilizer Microgeo $\AA, 15 \%$ of ruminal content and water are mixed in a tank exposed to a sunlight. After 15 days the biofertilizer is ready to be applied. SoilSoup ${ }^{\circledR}$ is an aerobic compost tea generated via fermentation of vermicompost over 24 hours with the addition of nutrient solution (molasses, bat 
Table 1. Products description and components.

\begin{tabular}{|c|c|c|c|c|}
\hline Resource & Category & Subcategory & Name & Components \\
\hline \multirow{2}{*}{ Organic } & \multirow{2}{*}{ Humate } & \multirow{2}{*}{ Humic acid } & Monty's Liquid Carbon & $\begin{array}{l}2 \% \text { humic acid and } 1 \% \text { organic carbon derived } \\
\text { from brown coal }\end{array}$ \\
\hline & & & $\begin{array}{l}\text { Microlife Humic } \\
\text { Acid Complex }\end{array}$ & $\begin{array}{l}15 \% \text { humic acid and } 1 \% \text { fulvic acid derived } \\
\text { from leonardite }\end{array}$ \\
\hline \multirow[t]{3}{*}{$\begin{array}{l}\text { Organic }+ \\
\text { Biological }\end{array}$} & \multirow{3}{*}{ Biofertilizer } & Manure tea & Microgeo & $\begin{array}{l}\text { recancitrant substances, biodynamic } \\
\text { preparations, pentoses, minerals and the } \\
\text { microorganisms produced in the manure tea } \\
\text { fermentation }\end{array}$ \\
\hline & & Compost tea & SoilSoup & $\begin{array}{l}\text { molasses, bat guano, sea bird guano, soluble } \\
\text { kelp, langbeinite, natural citric acid, ancient } \\
\text { seabed minerals, yucca and the } \\
\text { microorganisms produced in the compost } \\
\text { tea fermentation }\end{array}$ \\
\hline & & Bioinoculant & $\begin{array}{l}\text { Microgro Supreme } \\
\text { Bioinoculant }\end{array}$ & $\begin{array}{l}76 \text { different strains of bacteria and fungi placed } \\
\text { on dry milk carrier loaded with microbial } \\
\text { food. The microorganisms included are: } \\
\text { species of Genus Bacillus, Psuedomonas, } \\
\text { Streptomycetes, Trichoderma, and Endo and } \\
\text { Ectomycorrhizal Fungi }\end{array}$ \\
\hline
\end{tabular}

guano, sea bird guano, soluble kelp, langbeinite, natural citric acid, ancient seabed minerals, yucca) and oxygen to the system (aquarium pump). The Microgro Supreme Bioinoculant ${ }^{\circledR}$ is a water-soluble powder containing 76 strains of bacteria and fungi including 11 Mycorrhizal species and microbial food (sugars, humic acid, kelp, amino acids and yeast extract). All products are further described in Table 1.

One experiment was initiated in 2017 with two $\mathrm{N}$ sidedress rates of 107 and $134 \mathrm{~kg} \mathrm{~N} \mathrm{ha}$ applied as urea-ammonium nitrate (UAN, $30 \% \mathrm{~N})$ in a factorial arrangement with the individual and combined use of three biostimulant products. These sidedress rates corresponded to 80 and $100 \%$ of the recommended sidedress $\mathrm{N}$ rate based on corn yield goal at the Blacksburg location. The lack of a significant interaction between $\mathrm{N}$ rate and biostimulants led to a redesign of the experiment for 2018 and 2019. In the latter two years, a single $\mathrm{N}$ sidedress rate $\left(107 \mathrm{~kg} \mathrm{~N} \mathrm{ha}^{-1}\right.$ in Blacksburg and $178 \mathrm{~kg} \mathrm{~N} \mathrm{ha}^{-1}$ in Champlain) was homogeneously applied as urea-ammonium nitrate (UAN, $30 \% \mathrm{~N}$ ) in all plots and five total biostimulants were tested independently and in combination. A detailed description of management practices is presented in Table 2 while treatment combinations used in different years are shown in Tables 3 and 4.

The experimental design in each case was a randomized complete block design with 12 treatments and four replications with a plot size of $3 \mathrm{~m} \times 7.6 \mathrm{~m}$ and $0.61 \mathrm{~m}$ alley and corn planted in $76 \mathrm{~cm}$ rows. Corn hybrid, seeding rate, and field activities are presented in Table 2. Other management practices and inputs including weed and pest control and $\mathrm{P}$ and $\mathrm{K}$ application followed Virginia Cooperative Extension recommendations for corn production (Brann, Holshouser, and Mullins 2000).

Application rates of the organic and biological compounds were consistent with label recommendations for those products. They were applied to soil shortly before emergence and to plant foliage at corn growth stages V4, V7 and V11. The application rates were: Microgeo applied at $150 \mathrm{~L} \mathrm{ha}^{-1}$ applied full strength to soil and 3\% strength at V4, V7, V11; SoilSoup applied at $234 \mathrm{~L}$ $\mathrm{ha}^{-1}$, full strength; Microgro Supreme Bio applied at $6.1 \mathrm{~kg} \mathrm{ha}^{-1}$ diluted in $234 \mathrm{~L}$ of water; (2018 and 2019) and Monty's Liquid Carbon applied at $4.6 \mathrm{~L} \mathrm{ha}^{-1}$ diluted in $234 \mathrm{~L}$ of water and Microlife Humic at $14 \mathrm{~L} \mathrm{ha}^{-1}$ diluted in $234 \mathrm{~L}$ of water (2018 and 2019).

At V5, V10 and VT, plant height, plant greenness (ranked from 0-10, personal visual evaluation where 0 was less green and 10 was darker green), plant vigor (visual assessment from $0-10$, with 0 showing very poor vigor and 10 indicating greatest vigor), normalized vegetation index (NDVI) collected using a Greenseeker ${ }^{\circledR}$ model 505 handheld sensor unit (Trimble Navigation, Sunnyvale, CA) used according to the methodology of Govaerts and Verhulst (2010) and 
Table 2. Field activities and corn hybrid listing for experiments at Blacksburg and Champlain VA, 2017-2019.

\begin{tabular}{|c|c|c|c|c|}
\hline Field activity & Blacksburg & & & Champlain \\
\hline Planting date & 5/17/2017 & $5 / 16 / 2018$ & $4 / 29 / 2019$ & $4 / 23 / 2018$ \\
\hline Corn Hybrid & $\begin{array}{l}\text { Mid-Atlantic } \\
8146 \text { VT3P }\end{array}$ & $\begin{array}{l}\text { Mid-Atlantic } \\
8146 \text { VT3P }\end{array}$ & $\begin{array}{c}\text { Syngenta - } \\
\text { NK1354 }\end{array}$ & $\begin{array}{l}\text { Hubner } \\
\text { H4563 }\end{array}$ \\
\hline Population (plant ha ${ }^{-1}$ ) & 62,500 & 62,500 & 62,500 & 88,900 \\
\hline Side dress $\mathrm{N}$ fertilization date & $6 / 20 / 2017$ & $6 / 11 / 2018$ & $6 / 3 / 2019$ & $6 / 7 / 2018$ \\
\hline Harvest date & $11 / 1 / 2017$ & $10 / 23 / 2018$ & $9 / 18 / 2019$ & $9 / 4 / 2018$ \\
\hline
\end{tabular}

Table 3. Treatments arrangement during the year of 2017 in Blacksburg.

\begin{tabular}{|c|c|c|c|c|}
\hline \multirow[b]{2}{*}{ No. } & \multicolumn{4}{|c|}{ Treatments 2017} \\
\hline & Subcategory & Product Name and Abbreviation & Label (L/ha) & UAN (kg/ha) \\
\hline 1 & \multirow{2}{*}{ Humic } & Control (C) & 0 & 107 \\
\hline 2 & & Monty's $(H)$ & 4.6 & 107 \\
\hline 3 & \multirow{2}{*}{ Biofertilizer } & Microgeo (M) & 150 & 107 \\
\hline 4 & & SoilSoup (S) & 234 & 107 \\
\hline 5 & \multirow{2}{*}{ Humic + Biofertilizer } & Monty's + Microgeo $(\mathrm{H}+\mathrm{M})$ & 4.6 and 150 & 107 \\
\hline 6 & & Monty's + SoilSoup $(H+S)$ & 4.6 and 234 & 107 \\
\hline 7 & \multirow{2}{*}{ Humic } & Control $(C)$ & 0 & 134 \\
\hline 8 & & Monty's (H) & 4.6 & 134 \\
\hline 9 & \multirow{2}{*}{ Biofertilizer } & Microgeo (M) & 150 & 134 \\
\hline 10 & & SoilSoup (S) & 234 & 134 \\
\hline 11 & \multirow{2}{*}{ Humic + Biofertilizer } & Monty's + Microgeo $(\mathrm{H}+\mathrm{M})$ & 4.6 and 150 & 134 \\
\hline 12 & & Monty's + SoilSoup $(\mathrm{H}+\mathrm{S})$ & 4.6 and 234 & 134 \\
\hline
\end{tabular}

Table 4. Treatments arrangement in Blacksburg (2018 - 2019) and Champlain (2018).

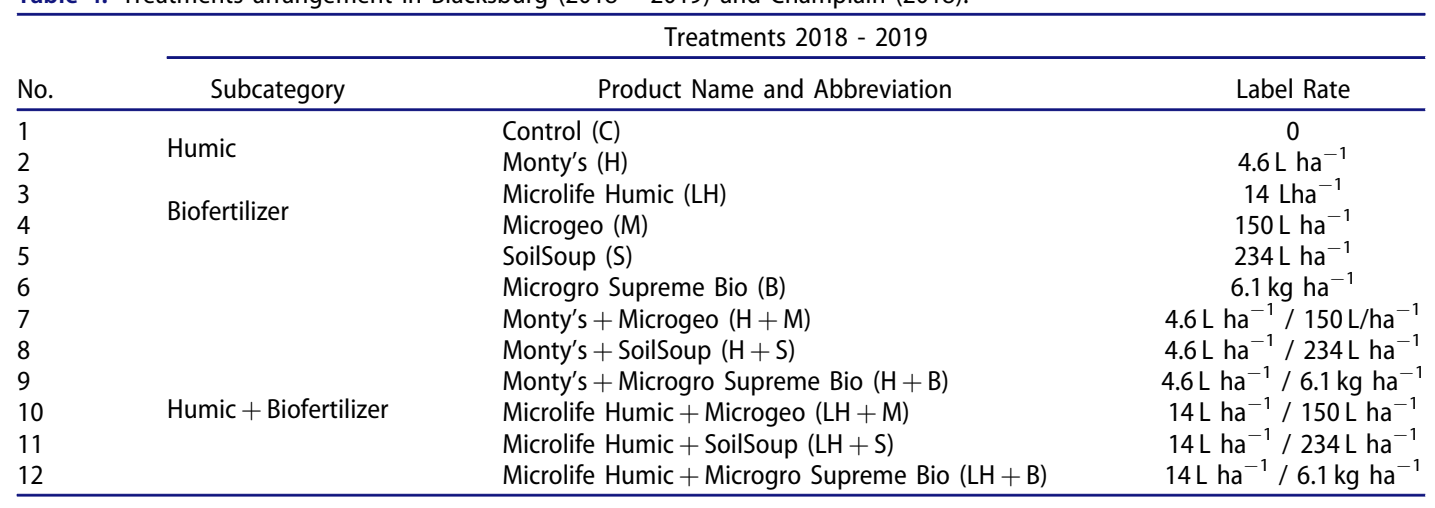

photosynthetic efficiency measured with an OS-50II fluorometer (Opti-Sciences, Tyngsboro, MA) (2018-2019). Corn was harvested from the center two rows of each plot using a Kincaid 8X (Kincaid Equipment Manufacturing, Haven, KS) small plot combine equipped with GrainGage system measuring total weight, moisture and test weight of each plot (Juniper Systems Inc., Logan, UT). A subsample of grain was collected to determine grain moisture using a Dickey-John (Dickey-John, Auburn, IL) and grain yield was adjusted to $155 \mathrm{~g} \mathrm{~kg}^{-1}$ moisture content. Grain subsamples were also analyzed for starch and protein content using near infrared spectroscopy (FOSS XDS, Eden Prairie, MN).

Analysis of variance was conducted using PROC GLIMMIX in SAS (SAS Institute 2017) to evaluate treatment effects on plant height, vigor, greenness, NDVI, photosynthetic efficiency (PE), grain yield and grain nutrient content. Biostimulant products and $\mathrm{N}$ rates were considered fixed effects, while experimental site, year and replication were considered random effects. In 2017, we initially screened the data for potentially important biostimulant by $\mathrm{N}$ rates interactions, but no significant interactions were found. Thus, our final statistical model for 2017 averaged over N 
rates. In the absence of biostimulant, location and year interactions in 2018 and 2019, statistical results were pooled over locations and years. In all years, mean separation was conducted using the Dunnett's option within the LSMEANS statement when F-tests indicated that significant differences existed $(\mathrm{p}<0.05)$ due to treatments.

\section{Results and discussion}

\section{Growing season environmental conditions}

Monthly average temperatures in the 2017 growing season in Blacksburg were above the 30 year average the entire growing season, April - October (Figure 1). The monthly average temperature in April was $5.5^{\circ} \mathrm{C}$ higher than the 30 year average, favoring early season corn growth and development. Rainfall was above normal in April, August and October, and considerably above normal in May. Below-normal rainfall occurred in June and September. The 2018-2019 season in Blacksburg and Champlain presented temperature and rainfall values that were above normal in
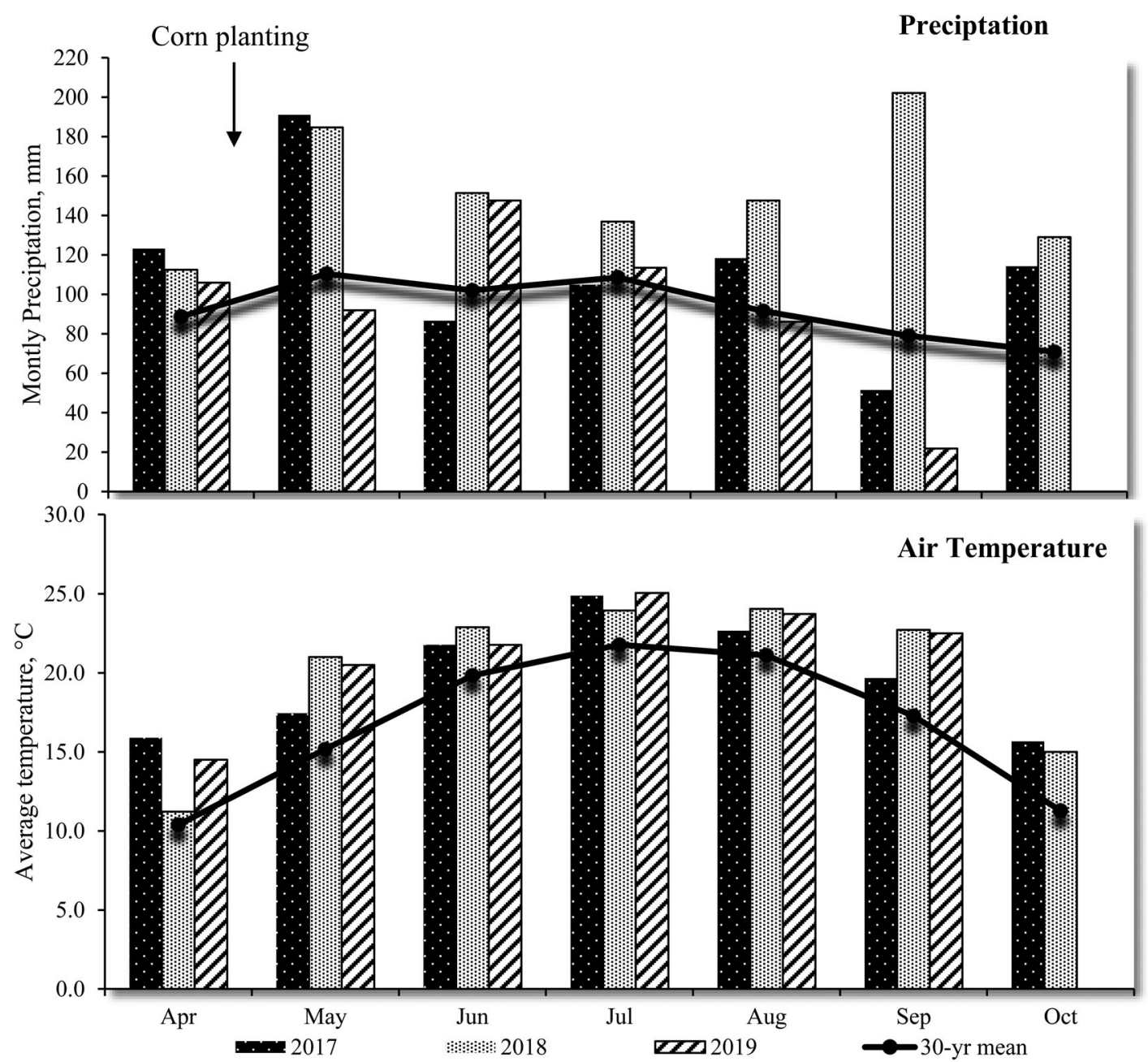

Figure 1. Average total monthly precipitation and monthly air temperature for the $2017-2019$ growing seasons in Blacksburg VA area. Data were collected at National Oceanic and Atmospheric Administration National Climatic Data Center (NOAA) website - https://www.ncdc.noaa.gov/cdo-web/. (accessed 1 Oct. 2019). Circular symbols connected by lines represent normal temperature and precipitation recorded from 1981-2010 in Virginia. 

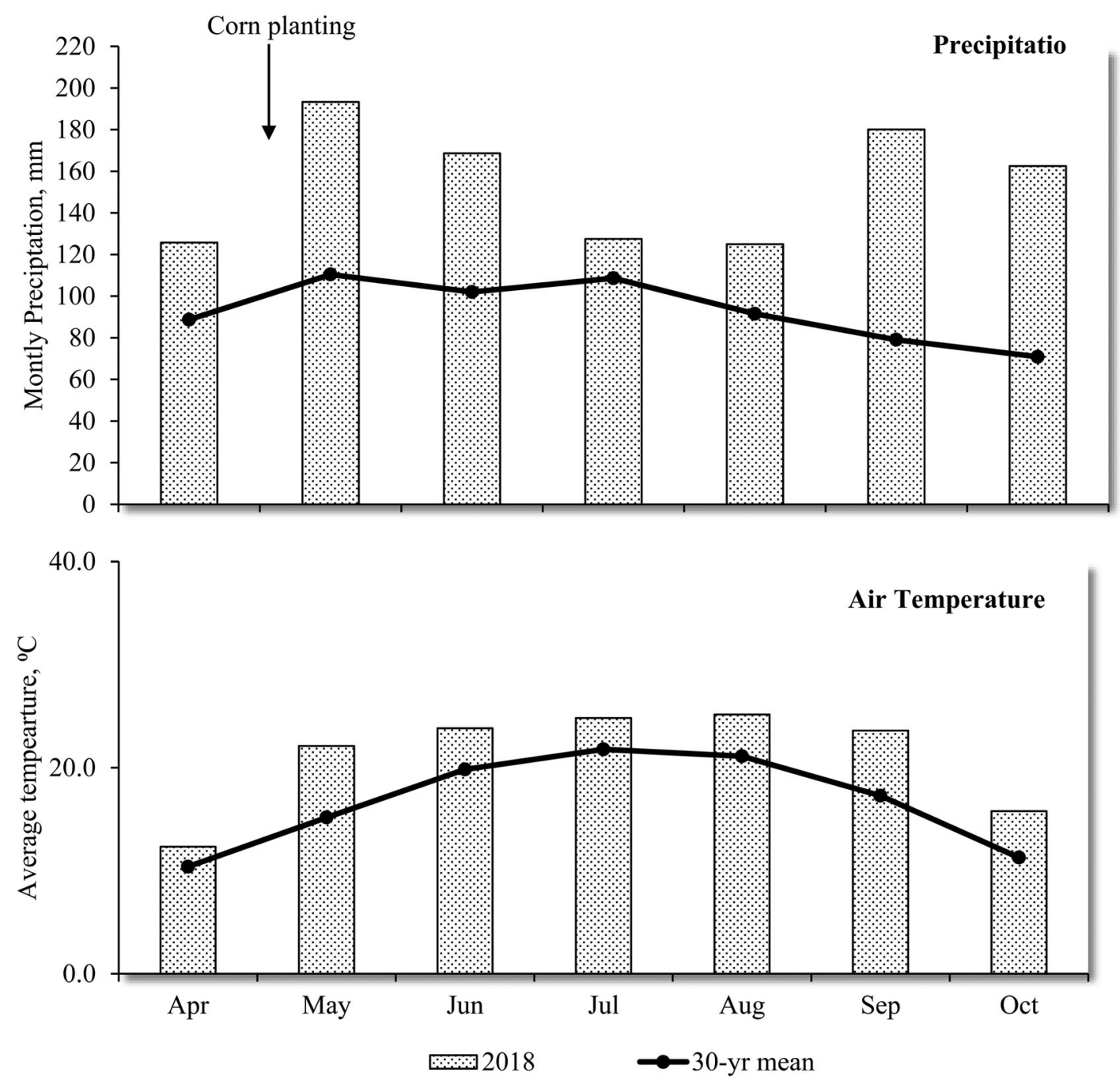

Figure 2. Average total monthly precipitation and monthly air temperature for the 2018 growing season in Champlain - VA area. Data were collected at National Oceanic and Atmospheric Administration National Climatic Data Center (NOAA) website https://www.ncdc.noaa.gov/cdo-web/. (accessed 1 Oct. 2019). Circular symbols connected by lines represent normal temperature and precipitation recorded from 1981-2010 in Virginia.

most of the season (Figures 1 and 2) except in Blacksburg in 2019, where the rainfall was lower than the 30 year average in May, August and September.

\section{Year 2017}

Analysis of variance found no significant interaction between $\mathrm{N}$ rates. Therefore, we combined the results obtained in both $\mathrm{N}$ rates for each biostimulant treatment (Table 5).

Plant height showed statistically significant differences only at the V5 growth stage, where all biostmulant treatments resulted in taller plants than the control. The use of HA and biofertilizers alone and in combination stimulated corn height similarly at V5. Previous work has demonstrated that increasing doses of HA applied directly to the soil (Daur and Bakhashwain 2013) and foliar application (Gaikwad et al. 2012) increased corn height, possibly due the mitigation of stress. Foliar HA application has resulted in greater corn height mainly under water deficit, but 
Table 5. Effects of the biostimulant treatments on corn height, NDVI, greenness and vigor, collected at V5, V10 and Tasseling growth stage in Blacksburg, 2017.

\begin{tabular}{|c|c|c|c|c|c|c|c|c|c|c|}
\hline \multirow{2}{*}{$\begin{array}{l}\text { Growth } \\
\text { stage }\end{array}$} & \multirow[b]{2}{*}{ Subcategory } & \multirow[b]{2}{*}{ Biostimulant treatment } & \multicolumn{8}{|c|}{ Difference between treatments and control values } \\
\hline & & & \multicolumn{2}{|c|}{ Height, $\mathrm{cm}$} & \multicolumn{2}{|c|}{ NDVI } & \multicolumn{2}{|c|}{ Greenness, rank ${ }^{\dagger}$} & \multicolumn{2}{|c|}{ Vigor, rank ${ }^{\ddagger}$} \\
\hline \multirow{6}{*}{ V5 } & Humic & Monty's & 5.3 & $*$ & 0.026 & & 0.6 & & 0.6 & \\
\hline & \multirow{5}{*}{ Humic + Biofertilizer } & Microgeo & 6.2 & $*$ & 0.060 & $*$ & 1.0 & $*$ & 0.8 & $*$ \\
\hline & & SoilSoup & 5.0 & * & 0.001 & & 0.5 & & 0.3 & \\
\hline & & Monty's + Microgeo & 8.5 & $*$ & 0.013 & & 0.6 & & 0.5 & \\
\hline & & Monty's + SoilSoup & 8.2 & $*$ & 0.012 & & 0.2 & & 0.4 & \\
\hline & & Actual Control Values & 66.2 & & 0.628 & & 8.1 & & 8.3 & \\
\hline \multirow{6}{*}{ V10 } & \multirow{3}{*}{$\begin{array}{c}\text { Humic } \\
\text { Biofertilizer }\end{array}$} & Monty's & 2.0 & & 0.030 & & 1.0 & ** & 0.8 & ** \\
\hline & & Microgeo & 2.2 & & 0.049 & & 0.8 & $* *$ & 0.6 & \\
\hline & & SoilSoup & 1.6 & & 0.031 & & 0.3 & & 0.5 & \\
\hline & \multirow{3}{*}{ Humic + Biofertilizer } & Monty's + Microgeo & 3.6 & & 0.063 & $* *$ & 1.1 & $* *$ & 0.7 & $* *$ \\
\hline & & Monty's + SoilSoup & 1.8 & & 0.049 & & 0.9 & $* *$ & 0.6 & \\
\hline & & Actual Control Values & 138.6 & & 0.710 & & 8.6 & & 9.0 & \\
\hline \multirow{6}{*}{ Tasseling } & Humic & Monty's & -5.6 & & 0.036 & $* * *$ & 1.0 & $* * *$ & 0.7 & $* * *$ \\
\hline & \multirow{5}{*}{ Humic + Biofertilizer } & Microgeo & 1.8 & & 0.034 & $* * *$ & 1.0 & $* * *$ & 0.6 & $* * *$ \\
\hline & & SoilSoup & -1.8 & & 0.023 & & 0.7 & $* * *$ & 0.6 & $* * *$ \\
\hline & & Monty's + Microgeo & 1.0 & & 0.033 & $* * *$ & 1.1 & $* * *$ & 0.7 & $* * *$ \\
\hline & & Monty's + SoilSoup & -2.2 & & 0.032 & $* * *$ & 0.9 & $* * *$ & 0.6 & $* * *$ \\
\hline & & Actual Control Values & 268.5 & & 0.789 & & 8.8 & & 9.2 & \\
\hline
\end{tabular}

$*, * *, * * *$ Means separation within each growth stage are significantly different as $\alpha<0.05$. tVisual assessment where 0 was less green and 10 was darker green.

$\neq$ Visual assessment where 0 showing very poor vigor and 10 indicating greatest vigor.

has been reported under full irrigation as well (Moghadam, Khamene, and Zahedi 2014; Abdulameer and Ahmed 2019). These four studies measured differences in corn height around tasseling but we found no differences at this stage in our studies. Also, these studies reported increased grain yield or dry biomass when HA was applied which was not observed in our study in 2017. Regarding the influence of HA on corn at early vegetative stages, Sun et al. (2016) found that different concentrations of HA increased corn seedling height under hydroponic conditions. Use of HA has also influenced height of other plant species such as millet (Panicum miliaceum L.) (Kuşvuran and Babat 2011), canola (Brassica Napus L.) (Sani 2014) and cucumber (Cucumis sativus L.) (El-Nemr et al. 2012). Various methods of HA application to plants have shown its influence on cell elongation (Vaughan 1974), nutrient uptake (Ayas and Gulser 2005), improved soil structure and water retention (Lobartini, Orioli, and Tan 1997) and hormone-like effects (Canellas et al. 2011). Thus, all these factors may contribute to increased corn height well as greater NDVI, greenness and vigor (Table 5). Furthermore, the application of HA to corn has increased dry biomass and forage harvest index and decreased the need for $\mathrm{P}$ fertilizer (Rezazadeh, Khorasani, and Haghighi, Kafi, and Fang 2012). In the current experiment, $\mathrm{N}$ fertilizer was the only macronutrient variable tested and the interaction HA was not significant. Varanini and Pinton (1995) stated that $\mathrm{N}$ release is influenced by humic substances but other soil factors such as $\mathrm{N}$ mineralization and microbial activity should be taken into consideration.

The biofertilizer treatments Microgeo and SoilSoup performed similarly in terms of corn height, with values that were statistically greater than the control in the individual applications and in combination with HA, but only at the V5 growth stage. Under greenhouse conditions an increasing dose of a bovine biofertilizer made in a very similar manner as the biofertilizer Microgeo, consistently increased corn height at 60 days after sowing, most likely due the presence of nitrogen in the biofertilizer (Viana et al. 2014). Regarding the integrated use of synthetic, organic and biological resources, studies addressing baby corn (Jinjala et al. 2016; Dadarwal, Jain, and Singh 2009), sweet corn (Mukhlis and Lestari 2014) and corn (Singh et al. 2018) reported that combining synthetic fertilizer + biofertilizer resulted in taller plants than the application of each resource alone. Moreover, Baloach et al. (2014) revealed that the application of biofertilizer alone and in combination with HA increased corn height when compared to the untreated 
control. Again, the height values in these corn studies previously mentioned were collected at tasseling and in the data from 2017 the biofertilizer treatments presented significant values only at V5 (Table 5). Mobasser and Moradgholi (2012) revealed that corn plant height and yield can vary substantially due to interaction between different biofertilizers strains and corn hybrids. Studies have shown that numerous types of biofertilizers have the potential to act on plant height, as a result of different mechanisms, such as nitrogen fixation in legumes and non-legumes (Dobereiner and Pedrosa 1987), solubilization of phosphates, micronutrient and minerals (Goldstein and Liu 1987; Wu et al. 2005), plant defence against biotic and/or abiotic stress (Mastouri 2010) and stimulation of plant growth regulators like auxins, gibberellins, and cytokinin (Contreras-Cornejo et al. 2009). These mechanisms might help to explain the positive effects of biofertilizers on NDVI, greenness and vigor as well.

The application of HA alone significantly increased NDVI values only at tasseling, but the combination HA + biofertilizer resulted in NDVI values significantly higher than control at V10 and Tasseling (Table 5). Zhu and Li (2018) compared the application of two rates of HA against the control (without HA) on turf grass in Colorado and North Dakota and found that HA significantly increased NDVI values at both rates and locations. Also, when comparing to control, HA applications resulted in higher NDVI from May through September, but this was only measured at V10 in 2017. Values of NDVI can be associated with chlorophyll concentration because reflectance of the specific wavelengths of light used in the equation to derive NDVI are very similar to those associated with production of chlorophyll (Ciganda, Gitelson, and Schepers 2009). According to Pishchik et al. (2016), the synergistic effect of HA + biofertilizer increased chlorophyll concentration of lettuce compared to the application of each compound alone.

The biofertilizer Microgeo had greater NDVI than SoilSoup with values greater than the control in the individual application at V5 and tasseling as well as in combination with HA at V10 and tasseling (Table 5). Viana et al. (2014) tested a liquid biofertilizer derived from bovine manure similar to Microgeo and the increasing doses caused significantly higher photosynthetic rates than the control. SoilSoup increased NDVI over the control only in combination with HA at tasseling (Table 5). The integrated use of two biofertilizers, where one of them contained HA, has statistically increased NDVI values of corn under deficit and normal irrigation (Shirkhani and Nasrolahzadeh 2016). Kazi et al. (2016) stated that while the application of biofertilizer did not significantly affect NDVI on wheat (Triticum aestivum L.), numerically higher values were found in inoculated plots compared to the uninoculated control. This may be similar to the observations in this experiment, where few treatments had NDVI values statistically higher than the control, however all the values were numerically higher.

Spectral reflectance (NDVI) can be an important indicator of stress for corn (Wang, Cherkauer, and Bowling 2016), which can be correlated to the visual quality parameters collected in this experiment (greenness and vigor). The treatments containing HA alone and HA + biofertilizer showed significantly higher greenness and vigor values at V10 and tasseling. The same study mentioned previously from $\mathrm{Zhu}$ and $\mathrm{Li}$ (2018), showed that the highest application rate of HA consistently had higher values of visual turf quality than the control from May through September in Colorado and North Dakota. In this case, the turf grass visual quality assessment followed the (Morris and Shearman 2000), which included color and plant density as criteria to grade the treatments. These two parameters were used to evaluate greenness and vigor, respectively, in this current experiment. de Melo, Baldotto, and Baldotto (2015) also found that corn responded positively to the application of HA and enhanced the initial corn vigor and crop's yield potential.

The biofertilizers alone and in combination with HA generally resulted in higher scores for greenness and vigor at V10 and tasseling (Table 5). The fact that most of the treatments presented numerically higher values than control in terms of height and NDVI might have impacted the visual grading for greenness and vigor. 
Table 6. Effects of the biostimulant treatments on corn NDVI, Photosynthetic Efficiency (PE), greenness and vigor, collected at V5, V10 and tasseling growth stage in Blacksburg, 2018 and 2019 and Champlain, 2018*.

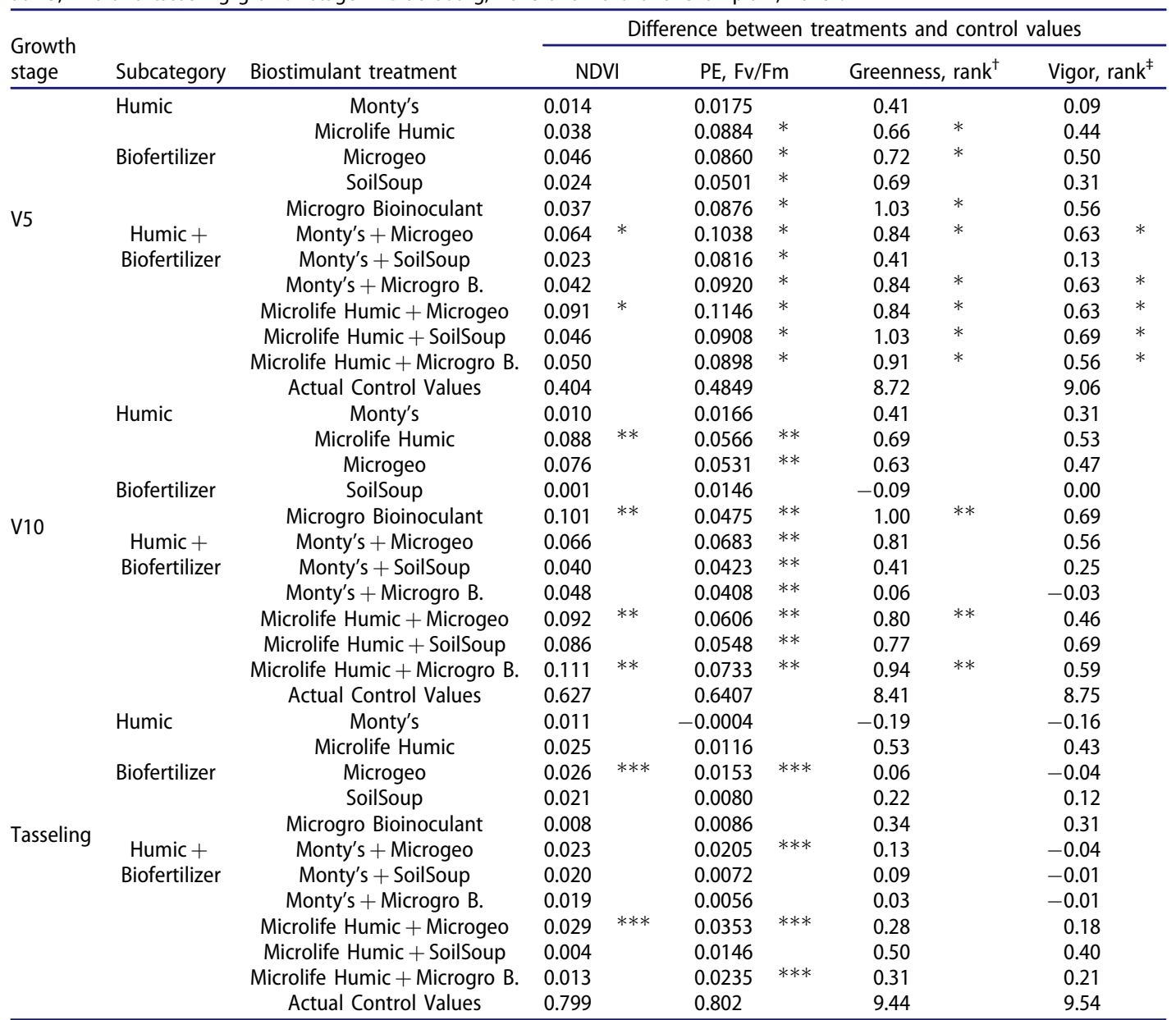

${ }^{¥}$ The data from 2018 and 2019 were combined due the lack of significance (treatments $\mathrm{x}$ growth stages $\mathrm{x}$ years interaction).

$*, * *, * * *$ Means separation within each growth stage are significantly different as $\alpha<0.05$.

${ }^{+}$Visual assessment where 0 was less green and 10 was darker green.

${ }^{\ddagger}$ Visual assessment where 0 showing very poor vigor and 10 indicating greatest vigor.

The other plant parameters collected in this experiment such as grain yield and nutrient content were not statistically influenced by the treatments.

\section{Year 2018 and 2019}

In Blacksburg in 2018 and 2019 and Champlain in 2018 80\% of the recommended N rate was consistently applied in all field trials. Furthermore, due to the lack of interaction, we combined the data from the two years in Blacksburg and one year in Champlain for each treatment (Table 6).

No effect of treatment on corn height was observed in studies in 2018 and 2019. El-Mekser, Mohamed, and Ali (2014) also found non-positive effects of HA on corn height when considering different locations and growing seasons. Similarly, habanero pepper (Capsicum chinense) did not show increased plant height in response to application of biofertilizer (Moreno-Salazar et al. 2019).

In 2017, we observed significant effect of Monty's HA application on NDVI at tasseling. However, in later years Monty's HA did not affect NDVI while the other HA product, Microlife Humic had NDVI values greater than the control when applied alone at V10 and with 
biofertilizer at all growth stages. We followed the label rate of each product and this resulted in a greater application rate of the Microlife Humic product. This product also had a higher concentration of HA compared to Monty's. There is clear evidence that different HA application rates and methods can promote different magnitude of effects or basically no effect (Yildirim 2007; Liu, Cooper, and Bowman 1998). According to Senesi and Brunetti (1996), HA parameters such as: molecular heterogeneity, aromaticity and structural polycondensation, aliphatic character, oxygen presence and acidity can impact economic value, agronomic efficacy and environmental safety of the final HA product. None of the characteristics mentioned above are included in the HA products label and even the method to quantify the level humic substances percent is not specifically described. However, institutions such as the Humic Products Trade Association are trying to standardize the main HA specifications included in the product label. Lamar et al. (2014) created a methodology for routine regulatory and industrial use to establish and verify contents of HA commercial products due the increasing use of humic substances in agriculture and the real necessity of farmers, consumers and regulators to obtain trustworthy information from the label.

As occurred in 2017, NDVI values were greater for the biofertilizer Microgeo than other biofertilizer treatments. In 2018-19, Microgeo alone increased NDVI values over the control at tasseling and in combination with Microlife Humic at all growth stages (Table 6). SoilSoup application did not result in any significant difference in NDVI and the application of Microgro Bioinoculant alone and in combination with Microlife Humic statistically increased NDVI values only at V10 (Table 6). Malik (2018) tested the seed inoculation of four biofertilizers applied independently and with two biofertilizers on barley (Hordeum vulgare L.) and none affected NDVI compared to the control (uninoculated). Other studies report no effect of biofertilizers on NDVI in wheat (Dal Cortivo et al. 2018) and soybean (Cerezini et al. 2016). Regarding this variability of biofertilizer performance on NDVI values, two wheat studies report that biofertilizer application did impact NDVI but other factors also influenced the magnitude of effects. Singh et al. (2019) assessed the integrated use of different biofertilizers and synthetic fertilizers and each biofertilizer impacted NDVI differently even under the treatments with the same synthetic input. Furthermore, the findings of Pagnani et al. (2020) showed significant differences in NDVI not only when the same biofertilizer was applied using different methods but also within three wheat varieties. Therefore, management aspects such as the nature of the biofertilizer, application method, crop, cultivar, interaction with other fertilizers and environmental conditions can affect the overall performance of biofertilizer on NDVI values. This statement might be valid for other parameter such as $\mathrm{PE}$, greenness, vigor and yield as well.

The effects of HA application on PE was not the same as NDVI. Generally, HA application affected PE values more frequently than NDVI considering the number of statistically significant results for both parameters (Table 6). According to Sellers (1987), NDVI can be an important index assessing biomass, leaf area index, absorbed photosynthetically active radiation and canopy photosynthetic capacity. However, this index might fail to assess some dynamic physiological mechanisms (Gamon, Peñuelas, and Field 1992) such as PE. The NDVI values of drought-tolerant evergreens were similar to what was observed in the current experiment, where NDVI did not proportionally change in accordance with variation in photosynthetic activity values (Running and Nemani 1988). Photosynthetic efficiency was greater with application of Microlife Humic than Monty's in 2018 and 2019 as well, based on frequency of statistically significant values in the individual and integrated application with biofertilizer. According to Haghighi, Kafi, and Fang (2012), even though the HA mechanisms to influence the biological activities in plants is not well defined, the application of $\mathrm{HA}$ on lettuce maximized photosynthetic activity due to enhancement of chlorophyll content and mesophyll conductance. More specifically regarding PE, using the same metrics $\mathrm{F}_{\mathrm{v}} / \mathrm{F}_{\mathrm{m}}$ (maximum quantum yield of photosystem II), there are several studies reporting that HA can increase PE, especially when the plants are exposed to stress conditions. Ozfidan-Konakci et al. (2018) used wheat to test two doses of HA with and without stress 
imposed by endogenous cadmium. The application of HA only significantly inhibited the reduction of $\mathrm{F}_{\mathrm{v}} / \mathrm{F}_{\mathrm{m}}$ on the plants under cadmium stress. Furthermore, application of HA increased values of $\mathrm{F}_{\mathrm{v}} / \mathrm{F}_{\mathrm{m}}$ on blond plantain (Plantago ovata) and mitigate the damage caused by salinity stress, possibly due improved nutrient uptake and physiological changes (Gholami, Samavat, and Ardebili 2013). Lotfi et al. (2018) tested the application of HA on rapeseed (Brassica napus L.) under different water regimes and found higher $\mathrm{F}_{\mathrm{v}} / \mathrm{F}_{\mathrm{m}}$ values. The $\mathrm{PE}$ or maximum quantum yield of photosystem II measured by $\mathrm{F}_{\mathrm{v}} / \mathrm{F}_{\mathrm{m}}$ is a very susceptible component of the photosynthetic process and according to Zhang and Sharkey (2009), stress conditions can result in an overreduction of the electron transport chain impacting photosynthetic efficiency.

The significant effects of the biofertilizers on PE values were more frequent than with NDVI, similarly to what happened to HA application (Table 6). A study previously mentioned also found chlorophyll content values significantly higher with the application of biofertilizer (Cerezini et al. 2016). Even though, chlorophyll content and PE can be relatable to some extent, this is further evidence that biofertilizers influence plants differently when comparing NDVI and PE. Generally, the influence of biofertilizers on PE was variable when considering the number of statistically significant values. However, SoilSoup and Microgro Biostimulant showed slightly lower efficacy than Microgeo on PE values. Microgeo application did not result in more statistical differences in PE as it did for NDVI values when comparing with the other biofertilizer products (Table 6). Photosynthetic efficiency has been widely used as a tool to evaluate the physiological condition of plants, especially to diagnose stress levels (Lichtenthaler and Rinderle 1988; Mészáros et al. 2001; Tóth et al. 2002). A reduction in PE values might be caused by damage to photosystem II (PSII) which can promote a reduction in $\mathrm{F}_{\mathrm{v}} / \mathrm{F}_{\mathrm{m}}$ (Porcar-Castell et al. 2014). Thus, PE values can be used to predict a plant's ability to mitigate stress. Gajdos et al. (2012) assessed the effects of a biofertilizer on corn and sunflower (Helianthus annuus L.) with and without cadmium stress, and the biofertilizer mitigated stress via higher $\mathrm{F}_{\mathrm{v}} / \mathrm{F}_{\mathrm{m}}$ only on corn. This again illustrates that the same biofertilizer can differentially affect PE values of different plant species even under the same environmental conditions. Another study addressing corn found that biofertilizer application mitigated the negative effects of nitrogen deprivation, where the treatments receiving biofertilizer had significantly higher $\mathrm{F}_{\mathrm{v}} / \mathrm{F}_{\mathrm{m}}$ under lower rates of nitrogen (Veres et al. 2007). Biofertilizers derived from different sources have also positively influenced PE values of safflower (Carthamus tinctorius L.) (Raheleh, Ghassemi, and Asghari 2019)and aloe vera (Aloe barbadensis Miller) (Khajeeyan et al. 2019) under drought stress and banana without any promoted stress conditions (Musa sapientum AAA group 'Kluai Hom Thong') (Theerawitaya et al. 2017).

Vigor, and, to a greater extent greenness and vigor were affected by HA application (Table 6). Similarly to our results, two previous studies have shown that $\mathrm{HA}$ increased $\mathrm{F}_{\mathrm{v}} / \mathrm{F}_{\mathrm{m}}$ values and visual greenness. Zhang et al. (2002) tested the effects of HA alone and in combination with seaweed and $\mathrm{FeSO}_{4}$ on creeping bentgrass (Agrostis palustris Huds.) in two growing seasons. Application of HA alone or combined with other products resulted in greater $F_{v} / F_{m}$ and greenness, but of differing magnitudes depending on the treatment and growing season. They also found that the increased $\mathrm{F}_{\mathrm{v}} / \mathrm{F}_{\mathrm{m}}$ values did not necessarily correspond to greater greenness as we observed in our experiment in 2018 and 2019. Another study addressing the use of HA and seaweed on creeping bentgrass also reported greater $\mathrm{F}_{\mathrm{v}} / \mathrm{F}_{\mathrm{m}}$ values and turf quality (visual score which greenness and vigor are considered) over two growing season (Zhang, Ervin, and Schmidt 2003). Evidence of the specific mechanism through which HA influences NDVI and PE is lacking. However, a review made by Canellas et al. (2015), provided a detailed understanding of the potential HA pathways to impact nutrient uptake and plant metabolism. In summary, this review presented evidence of the biostimulant effect of HA on structural and physiological changes in roots and shoots related to nutrient use efficiency. Additionally, they describe the important influence on plant primary and secondary metabolism associated with mitigating stress conditions. Regarding secondary metabolites, greater levels of auxins (Aldesuquy 2000) and glycine-betaine 


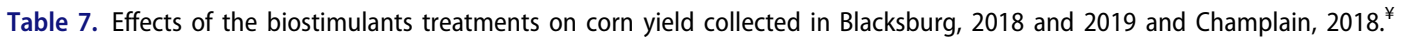

\begin{tabular}{|c|c|c|c|}
\hline \multirow[b]{2}{*}{ Subcategory } & \multirow[b]{2}{*}{ Biostimulant treatment } & \multicolumn{2}{|c|}{ Difference between treatments and control values } \\
\hline & & Yield, $\mathrm{kg} \mathrm{ha}^{-1}$ & Yield, bu ac ${ }^{-1}$ \\
\hline \multirow{3}{*}{ Humic } & Monty's & 322.44 & 5.76 \\
\hline & Microlife Humic & 734.13 & 13.68 \\
\hline & Microgeo & 1020.13 & 18.80 \\
\hline \multirow[t]{5}{*}{ Biofertilizer } & SoilSoup & 120.75 & 1.86 \\
\hline & Microgro Bioinoculant & 557.30 & 10.63 \\
\hline & Monty's + Microgeo & 1204.69 & 22.21 \\
\hline & Monty's + SoilSoup & 841.69 & 15.65 \\
\hline & Monty's + Microgro B. & 772.75 & 14.08 \\
\hline \multirow[t]{4}{*}{ Humic + Biofertilizer } & Microlife Humic + Microgeo & $1713.81^{*}$ & $30.25^{*}$ \\
\hline & Microlife Humic + SoilSoup & 1190.25 & 22.01 \\
\hline & Microlife Humic + Microgro B. & 1133.81 & 20.55 \\
\hline & Actual Control Values & 9123.13 & 178.42 \\
\hline
\end{tabular}

${ }^{¥}$ The data from 2018 and 2019 were combined due the lack of significance (treatments $\mathrm{x}$ growth stages $\mathrm{x}$ years interaction).

*Means separation are significantly different as $\alpha<0.05$.

(Papageorgiou, Fujimura, and Murata 1991) are related to cell membrane stabilization and consequently greater efficiency of photosystem II (PSII) when plants are under stress. Thus, these factors might elucidate the effects on NDVI, PE (maximum quantum yield of photosystem II), greenness and vigor (plant quality).

The application of HA resulted in similar ratings, likely due the fact that visual greenness and vigor estimates can be relatable, and these data were collected at the same time. However, estimates of greenness seemed to be slightly more affected by the application of biofertilizers compared to estimates of vigor (Table 6). Baltzoi et al. (2015) evaluated the effects of three biofertilizers on turfgrass (Festuca arundinacea) under 50\% and $100 \%$ water regimes, and the application of two biofertilizers compensated for the lack of water on the treatments under $50 \%$ water supply, showing similar turfgrass quality to full irrigation treatments. Therefore, it shows the potential of biofertilizers increasing quality parameters as greenness and vigor under stress conditions.

\subsubsection{Corn yield}

The integrated use of HA and biofertilizer (Microlife Humic + Microgeo) was the only treatment that resulted in corn yield greater than the control in 2018 and 2019 studies (Table 7). Even though only one treatment among twelve presented significantly higher grain yield, the results from 2018 and 2019 combined more closely approximated our initial hypothesis which was that synergy of HA + biofertilizer applied together would increase corn yield compared to each of the products applied individually and the control. Darvishi et al. (2010) reported strong correlation between corn PE $\left(\mathrm{F}_{\mathrm{v}} / \mathrm{F}_{\mathrm{m}}\right)$ and corn grain yield, in contrast to what was observed in 2018-2019, where differences in PE were observed with various treatments only one regarding grain yield. In fact, only one treatment among six treatments under the integrated use of HA and biofertilizer increased corn yield, but an increment of $1714 \mathrm{~kg} \mathrm{ha}^{-1}(18 \%)$ is substantial. Furthermore, all the treatments showed numerically higher yield when comparing to control and the numbers had to be higher than $1205 \mathrm{~kg} \mathrm{ha}^{-1}$ or 22 bushels acre ${ }^{-1}$ in order to present significance in the statistical analysis. In a practical manner, the yield increment presented by all the treatments might be considerable to the producer but in scientific standards the level of significance was set and not reached. Canellas et al. (2013) conducted two experiments (greenhouse and field trials) to evaluate the effects of HA + biofertilizer on corn development. In the greenhouse experiment, the individual and combined application of $\mathrm{HA}$ and biofertilizer generally increased plant metabolism (plasma membrane $\mathrm{H}+$-ATPase activity), sugar content and net photosynthesis. The treatment receiving the optimal dose of $\mathrm{HA}+$ biofertilizer had the greatest level of viable bacterial cells in 
root tissues. In the field trials, the combination of HA + biofertilizer increased corn yield in $65 \%$. Application of HA increased corn root exudates into the rhizosphere (Puglisi et al. 2008; Canellas et al. 2008), thus the biofertilizer could be used as a carbon substrate by microbes. Another study addressing corn reported that application of HA, either alone or with biofertilizer maximized corn yield, however the highest gains were observed by the integrated use of both compounds (Baloach et al. 2014). The integrated use of HA and biofertilizers resulted in greatest wheat grain and straw yield, likely due the enhancement if enzymes activity, available nutrients in the rhizosphere and photosynthetic pigments (Abou-Aly and Mady 2009).

\section{Conclusion}

These studies were designed to better elucidate the effects of the individual and combined application of HA and biofertilizers on corn also receiving conventional fertilizing practices. The individual and combined application of HA and biofertilizer following the Integrated Plant Nutrition System (IPNS) generally influenced corn development, to varying degrees. In 2017, corn height, NDVI, greenness and vigor were sensitive to the application of biostimulants in different magnitudes and growth stages, however grain yield and nutrient content were not affected. In combined studies from 2018 and 2019 corn height was not impacted by biostimulant application but NDVI, $\mathrm{PE}$, greenness and vigor were affected at different doses and corn growth stages. The combined use of HA + biofertilizer (Microlife Humic + Microgeo) was the only treatment leading to increased grain yield. In sum, these studies provided evidence that the individual and combined application of HA and biofertilizer can influence corn growth and vigor at various points during the growing season. However, the current study cannot conclusively affirm that the integrated use of HA and biofertilizers (IPNS) is a better practice than the application of each compound individually. The intensive labor required to apply these biostimulants four times during the growing season is also a factor to be considered, but the objective of this study was strictly to assess the efficacy of the products on corn development. Therefore, further studies addressing different application frequency and rates should be conducted to validate these findings and contribute further to the understanding of the value and viability of the IPNS approach in a farming scene.

\section{Disclosure statement}

No potential conflict of interest was reported by the authors.

\section{Funding}

This work was supported by Virginia Tech - College of Agriculture and Life Sciences.

\section{ORCID}

Jose Franco Da Cunha Leme Filho (D) http://orcid.org/0000-0002-4192-5945

\section{References}

Abdulameer, O. Q., and S. A. Ahmed. 2019. Role of humic acid in improving growth characters of corn under water stress. The Iraqi Journal of Agricultural Science 50 (1):420-30.

Abou-Aly, H. E., and M. A. Mady. 2009. Complemented effect of humic acid and biofertilizers on wheat (Triticum aestivum L.) productivity. Annals of Agricultural Science Moshtohor 47 (1):1-12.

Adesemoye, A. O., and J. W. Kloepper. 2009. Plant-microbes interactions in enhanced fertilizer-use efficiency. Applied Microbiology and Biotechnology 85 (1):1-12. doi: 10.1007/s00253-009-2196-0. 
Adesemoye, A. O., H. A. Torbert, and J. W. Kloepper. 2008. Enhanced plant nutrient use efficiency with PGPR and AMF in an integrated nutrient management system. Canadian Journal of Microbiology 54 (10):876-86. doi: 10.1139/w08-081.

Ahmed, S. 1995. Agriculture-fertilizer interface in Asia: Issues of growth and sustainability: Honolulu, Hawaii: Science Publishers.

Aldesuquy, H. S. 2000. Effect of indol-3-yl acetic acid on photosynthetic characteristics of wheat flag leaf during grain filling. Photosynthetica 38 (1):135-41.

Aulakh, M. S., and C. A. Grant. 2008. Integrated nutrient management for sustainable crop production. Boca Raton, FL: CRC Press.doi: 10.1201/9780367803216.

Ayas, H., and F. Gulser. 2005. The effects of sulfur and humic acid on yield components and macronutrient contents of spinach (Spinacia Oleracea Var. Spinoza). Journal of Biological Sciences 5 (6):801-4.

Baldotto, L. E., and M. A. Baldotto. 2014. Adventitious rooting on the Brazilian red-cloak and sanchezia after application of indole-butyric and humic acids. Horticultura Brasileira 32 (4):434-9. doi: 10.1590/S0102053620140000400010 .

Baloach, N., M. Yousaf, W. P. Akhter, S. Fahad, B. Ullah, G. Qadir, and Z. I. Ahmed. 2014. Integrated effect of phosphate solubilizing bacteria and humic acid on physiomorphic attributes of maize. International Journal of Current Microbiology and Applied Sciences 3:549-54.

Baltzoi, P., I. Tsirogiannis, D. Dimou, O. Kostoula, P. Yfanti, and G. Patakioutas. 2015. Effect of Symbiotic Microorganisms on Turfgrass under Two Irrigation Regimes. International Journal of Plant \& Soil Science 8 (2): 1-9. doi: 10.9734/IJPSS/2015/19359.

Barea, J. M., M. Toro, and R. Azcón. 2007. The use of 32P isotopic dilution techniques to evaluate the interactive effects of phosphate-solubilizing bacteria and mycorrhizal fungi at increasing plant $\mathrm{P}$ availability. In First International Meeting on Microbial Phosphate Solubilization. Developments in Plant and Soil Sciences. Vol. 102, eds. E. Velázquez and C. Rodríguez-Barrueco. Dordrecht: Springer. 10.1007/978-1-4020-5765-6_33

Bashan, Y. 1998. Inoculants of plant growth-promoting bacteria for use in agriculture. Biotechnology Advances 16 (4):729-70. doi: 10.1016/S0734-9750(98)00003-2.

Bhattacharjee, R. B., A. Singh, and S. N. Mukhopadhyay. 2008. Use of nitrogen-fixing bacteria as biofertiliser for non-legumes: Prospects and challenges. Applied Microbiology and Biotechnology 80 (2):199-209. doi: 10.1007/ s00253-008-1567-2.

Brann, D. E., D. L. Holshouser, and G. L. Mullins. 2000. Agronomy handbook. Pub. No. 424-100. Blacksburg, VA: Virginia Coop. Ext.

Bulgari, R., G. Cocetta, A. Trivellini, P. Vernieri, and A. Ferrante. 2015. Biostimulants and crop responses: A review. Biological Agriculture \& Horticulture 31 (1):1-17. doi: 10.1080/01448765.2014.964649.

Calvo, P., L. Nelson, and J. W. Kloepper. 2014. Agricultural uses of plant biostimulants. Plant and Soil 383 (1-2): 3-41. doi: 10.1007/s11104-014-2131-8.

Canellas, L. P., D. M. Balmori, L. O. Médici, N. O. Aguiar, E. Campostrini, R. C. C. Rosa, A. R. Façanha, and F. L. Olivares. 2013. A combination of humic substances and Herbaspirillum seropedicae inoculation enhances the growth of maize (Zea mays L.). Plant and Soil 366 (1-2):119-32. doi: 10.1007/s11104-012-1382-5.

Canellas, L. P., D. J. Dantas, N. O. Aguiar, L. E. P. Peres, A. Zsögön, F. L. Olivares, L. B. Dobbss, A. R. Façanha, A. Nebbioso, and A. Piccolo. 2011. Probing the hormonal activity of fractionated molecular humic components in tomato auxin mutants. Annals of Applied Biology 159 (2):202-11.

Canellas, L. P., and F. L. Olivares. 2014. Physiological responses to humic substances as plant growth promoter. Chemical and Biological Technologies in Agriculture 1 (1):3. doi: 10.1186/2196-5641-1-3.

Canellas, L. P., F. L. Olivares, N. O. Aguiar, D. L. Jones, A. Nebbioso, P. Mazzei, and A. Piccolo. 2015. Humic and fulvic acids as biostimulants in horticulture. Scientia Horticulturae 196:15-27. doi: 10.1016/j.scienta.2015.09.013.

Canellas, L. P., L. R. L. Teixeira Junior, L. B. Dobbss, C. A. Silva, L. O. Medici, D. B. Zandonadi, and A. R. Façanha. 2008. Humic acids crossinteractions with root and organic acids. Annals of Applied Biology 153 (2): $157-166$.

Cerezini, P., B. H. Kuwano, M. B. dos Santos, F. Terassi, M. Hungria, and M. A. Nogueira. 2016. Strategies to promote early nodulation in soybean under drought. Field Crops Research 196:160-7.

Chang, L., Y. Wu, WWei Xu, A. Nikbakht, and Y. Xia. 2012. Effects of calcium and humic acid treatment on the growth and nutrient uptake of Oriental lily. African Journal of Biotechnology 11 (9):2218-22.

Chen, Y., and T. Aviad. 1990. Effects of humic substances on plant growth 1. In Humic substances in soil and crop sciences: Selected readings, eds. P. MacCarthy, C. E. Clapp, R. L. Malcolm, and P. R. Bloom, 161-86. Madison, WI: Soil Science Society of America.

Ciganda, V., A. Gitelson, and J. Schepers. 2009. Non-destructive determination of maize leaf and canopy chlorophyll content. Journal of Plant Physiology 166 (2):157-67. doi: 10.1016/j.jplph.2008.03.004.

Contreras-Cornejo, H. A., L. Macías-Rodríguez, C. Cortés-Penagos, and J. López-Bucio. 2009. Trichoderma virens, a plant beneficial fungus, enhances biomass production and promotes lateral root growth through an auxindependent mechanism in Arabidopsis. Plant Physiology 149 (3):1579-92. doi: 10.1104/pp.108.130369. 
Dadarwal, R. S., N. K. Jain, and D. Singh. 2009. Integrated nutrient management in baby corn (Zea mays). Indian Journal of Agricultural Sciences 79 (12):1023-5.

Dal Cortivo, C., G. Barion, M. Ferrari, G. Visioli, L. Dramis, A. Panozzo, and T. Vamerali. 2018. Effects of field inoculation with vam and bacteria consortia on root growth and nutrients uptake in common wheat. Sustainability 10 (9):3286. doi: 10.3390/su10093286.

D'Andrea, P. A. 2002. Continuous liquid composting process - CLC and biofertilizer. Microbiol Industry and Trade LTDA. (BR/SP). N²099 Registro PI0207342-0 A2.

Darvishi, M., F. Paknezhad, A. Kashani, M. Ardakani, and M. Darvishi. 2010. Effect of drought stress and leaf nutrition of some elements of low Pramtrhay chlorophyll fluorescence, RWC, chlorophyll content, membrane stability and yield of maize. Iranian Journal of Crop Sciences 41 (3):531-43.

Daur, I., and A. A. Bakhashwain. 2013. Effect of humic acid on growth and quality of maize fodder production. Pakistan Journal of Botany 45 (S1):21-5.

de Melo, R. O., M. A. Baldotto, and L. E. B. Baldotto. 2015. Corn initial vigor in response to humic acids from bovine manure and poultry litter. Semina: Ciências Agrárias 36 (1):1863-74.

Dobereiner, J., and F. O. Pedrosa. 1987. Nitrogen-fixing bacteria in nonleguminous crop plants. Madison, WI: Science Tech Publishers.

El-Habbasha, S. F., M. Hozayn, and M. A. Khalafallah. 2007. Integration effect between phosphorus levels and biofertilizers on quality and quantity yield of faba bean (Vicia faba L.) in newly cultivated sandy soils. Research Journal of Agriculture and Biological Sciences 3 (6):966-71.

El-Mekser, H. K. A., Z. E. M. Mohamed, and M. A. M. Ali. 2014. Influence of humic acid and some micronutrients on yellow corn yield and quality. World Applied Sciences Journal 32 (1):1-11.

El-Nemr, M. A., M. El-Desuki, A. M. El-Bassiony, and Z. F. Fawzy. 2012. Response of growth and yield of cucumber plants (Cucumis sativus L.) to different foliar applications of humic acid and bio-stimulators. Australian Journal of Basic and Applied Sciences 6 (3):630-7.

Ferrara, G., and G. Brunetti. 2010. Effects of the times of application of a soil humic acid on berry quality of table grape (Vitis vinifera L.) cv Italia. Spanish Journal of Agricultural Research 8 (3):817. doi: 10.5424/1283.

Frink, C. R., P. E. Waggoner, and J. H. Ausubel. 1999. Nitrogen fertilizer: Retrospect and prospect. Proceedings of the National Academy of Sciences of the United States of America 96 (4):1175-80. doi: 10.1073/pnas.96.4.1175.

Gaikwad, S. B., R. D. Deotale, A. P. Uke, and L. B. Parihar. 2012. Influence of foliar sprays of humic acid through vermicompost wash on growth, yield and yield contributing parameters of maize. Journal of Soils and Crops 22 (1):115-21.

Gajdos, É., L. Lévai, S. Veres, and B. Kovács. 2012. Effects of biofertilizers on maize and sunflower seedlings under cadmium stress. Communications in Soil Science and Plant Analysis 43 (1-2):272-9.

Gamon, J. A., J. Peñuelas, and C. B. Field. 1992. A narrow-waveband spectral index that tracks diurnal changes in photosynthetic efficiency. Remote Sensing of Environment 41 (1):35-44. doi: 10.1016/0034-4257(92)90059-S.

Gholami, H., S. Samavat, and Z. O. Ardebili. 2013. The alleviating effects of humic substances on photosynthesis and yield of Plantago ovate in salinity conditions. International Research Journal of Applied and Basic Sciences 4 (7):1683-6.

Goel, A. K., R. D. Laura, D. V. Pathak, and A. Goel. 1999. Use of biofertilizers: Potential, constraints and future strategies-a review. International Journal of Tropical Agriculture 17 (1-4):1-18.

Goldstein, A. H., and S. T. Liu. 1987. Molecular cloning and regulation of a mineral phosphate solubilizing gene from Erwinia herbicola. Nature Biotechnology 5 (1):72-4.

Govaerts, B., and N. Verhulst. 2010. The normalized difference vegetation index (NDVI) Greenseeker (TM) handheld sensor: Toward the integrated evaluation of crop management part A: Concepts and case studies. Mexico, DF: CIMMYT.

Haghighi, M., M. Kafi, and P. Fang. 2012. Photosynthetic activity and N metabolism of lettuce as affected by humic acid. International Journal of Vegetable Science 18 (2):182-9. doi: 10.1080/19315260.2011.605826.

Hodge, A., C. D. Campbell, and A. H. Fitter. 2001. An arbuscular mycorrhizal fungus accelerates decomposition and acquires nitrogen directly from organic material. Nature 413 (6853):297-9. doi: 10.1038/35095041.

Jinjala, V. R., H. M. Virdia, N. N. Saravaiya, and A. D. Raj. 2016. Effect of integrated nutrient management on baby corn (Zea mays L.). Agricultural Science Digest 36 (4):291-4.

Kazi, N., R. Deaker, N. Wilson, K. Muhammad, and R. Trethowan. 2016. The response of wheat genotypes to inoculation with Azospirillum brasilense in the field. Field Crops Research 196:368-78. doi: 10.1016/j.fcr.2016.07. 012.

Khajeeyan, R., S. Amin, M. M. Dehnavi, H. Farajee, and M. A. Kohanmoo. 2019. Physiological and yield responses of Aloe vera plant to biofertilizers under different irrigation regimes. Agricultural Water Management 225: 105768. doi: 10.1016/j.agwat.2019.105768.

Kim, M. J., C. K. Shim, Y. K. Kim, S. J. Hong, J. H. Park, E. J. Han, J. H. Kim, and S. C. Kim. 2015. Effect of aerated compost tea on the growth promotion of lettuce, soybean, and sweet corn in organic cultivation. The Plant Pathology Journal 31 (3):259-68. doi: 10.5423/PPJ.OA.02.2015.0024. 
Kuşvuran, V. S. A., and S. Babat. 2011. The effect of different humic acid fertilization on yield and yield components performances of common millet (Panicum miliaceum L.). Scientific Research and Essays 6 (3):663-9.

Lamar, R. T., D. C. Olk, L. Mayhew, and P. R. Bloom. 2014. A new standardized method for quantification of humic and fulvic acids in humic ores and commercial products. Journal of AOAC International 97 (3):721-30. doi: 10.5740/jaoacint.13-393.

Lichtenthaler, H. K., and U. Rinderle. 1988. The role of chlorophyll fluorescence in the detection of stress conditions in plants. C R C Critical Reviews in Analytical Chemistry 19 (sup1):S29-S85. doi: 10.1080/15476510.1988. 10401466.

Liu, C., R. J. Cooper, and D. C. Bowman. 1998. Humic acid application affects photosynthesis, root development, and nutrient content of creeping bentgrass. HortScience 33 (6):1023-5. doi: 10.21273/HORTSCI.33.6.1023.

Lobartini, J. C., G. A. Orioli, and K. H. Tan. 1997. Characteristics of soil humic acid fractions separated by ultrafiltration. Communications in Soil Science and Plant Analysis 28 (9-10):787-96.

Lotfi, R., H. M. Kalaji, G. R. Valizadeh, E. Khalilvand Behrozyar, A. Hemati, P. Gharavi-Kochebagh, and A. Ghassemi. 2018. Effects of humic acid on photosynthetic efficiency of rapeseed plants growing under different watering conditions. Photosynthetica, 56:1-9.

Malik, P. 2018. Response of barley to fertilizer levels and different combinations of biofertilizers. Doctoral dissertation, CCSHAU.

Mastouri, F. 2010. Use of Trichoderma Spp. to improve plant performance under abiotic stresses [Dissertation], Cornell University.

Mészáros, I., R. Láposi, S. Veres, E. Bai, G. Lakatos, A. Gáspár, and O. Mile. 2001. Effects of supplemental UV-B and drought stress on photosynthetic activity of sessile oak (Quercus petraea L.). Science Access 3 (1).

Mobasser, H. R., and A. Moradgholi. 2012. Mycorrhizal bio-fertilizer applications on yield seed corn varieties in Iran. Annals of Biological Research 3 (2):1109-1116.

Moghadam, H. R. T., M. K. Khamene, and H. Zahedi. 2014. Effect of humic acid foliar application on growth and quantity of corn in irrigation withholding at different growth stages. Maydica 59 (2):124-8.

Moreno-Salazar, R., I. Sánchez-García, W. Chan-Cupul, E. Ruiz-Sánchez, H. A. Hernández-Ortega, J. Pineda-Lucatero, and D. Figueroa-Chávez. 2019. Plant growth, foliar nutritional content and fruit yield of Capsicum chinense biofertilized with Purpureocillium lilacinum under greenhouse conditions. Scientia Horticulturae, 261:108950.

Morris, K., and R. Shearman. 2000. NTEP turfgrass evaluation guidelines. National Turfgrass Evaluation Program.

Mukhlis, M., and Y. Lestari. 2014. Effects of biofertilizer "M-star" on land productivity and growth of sweet corn in acid sulphate soil of swampland. AGRIVITA, Journal of Agricultural Science 35 (3):242-8.

Nardi, S., G. Concheri, and G. Dell'Agnola. 1996. Chapter 9 - Biological activity of humus. In Humic substances in terrestrial ecosystems, ed. A. Piccolo, 361-406. Amsterdam: Elsevier Science B.V.

Ozfidan-Konakci, C., E. Yildiztugay, M. Bahtiyar, and M. Kucukoduk. 2018. The humic acid-induced changes in the water status, chlorophyll fluorescence and antioxidant defense systems of wheat leaves with cadmium stress. Ecotoxicology and Environmental Safety 155:66-75. doi: 10.1016/j.ecoenv.2018.02.071.

Pagnani, G., A. Galieni, F. Stagnari, M. Pellegrini, M. Del Gallo, and M. Pisante. 2020. Open field inoculation with PGPR as a strategy to manage fertilization of ancient Triticum genotypes. Biology and Fertility of Soils 56 (1): $111-4$.

Papageorgiou, G. C., Y. Fujimura, and N. Murata. 1991. Protection of the oxygen-evolving photosystem II complex by glycinebetaine. Biochimica et Biophysica Acta (BBA)-Bioenergetics 1057 (3):361-6.

Peoples, M. B., and E. T. Craswell. 1992. Biological nitrogen fixation: Investments, expectations and actual contributions to agriculture. Plant and Soil 141 (1-2):13-39. doi: 10.1007/bf00011308.

Pettit, R. E. 2004. Organic matter, humus, humate, humic acid, fulvic acid and humin: Their importance in soil fertility and plant health. CTI Research:1-17.

Pishchik, V. N., N. I. Vorobyov, O. S. Walsh, V. G. Surin, and Y. V. Khomyakov. 2016. Estimation of synergistic effect of humic fertilizer and Bacillus subtilis on lettuce plants by reflectance measurements. Journal of Plant Nutrition 39 (8):1074-86. doi: 10.1080/01904167.2015.1061551.

Porcar-Castell, A., E. Tyystjärvi, J. Atherton, C. Van der Tol, J. Flexas, E. E. Pfündel, J. Moreno, C. Frankenberg, and J. A. Berry. 2014. Linking chlorophyll a fluorescence to photosynthesis for remote sensing applications: Mechanisms and challenges. Journal of Experimental Botany 65 (15):4065-95.

Puglisi, E., G. Fragoulis, A. A. Del Re, R. Spaccini, A. Piccolo, G. Gigliotti, D. Said-Pullicino, and M. Trevisan. 2008. Carbon deposition in soil rhizosphere following amendments with compost and its soluble fractions, as evaluated by combined soil-plant rhizobox and reporter gene systems. Chemosphere 73 (8):1292-9. doi: 10.1016/ j.chemosphere.2008.07.008.

Puglisi, E., G. Fragoulis, P. Ricciuti, F. Cappa, R. Spaccini, A. Piccolo, M. Trevisan, and C. Crecchio. 2009. Effects of a humic acid and its size-fractions on the bacterial community of soil rhizosphere under maize (Zea mays L.). Chemosphere 77 (6):829-37. doi: 10.1016/j.chemosphere.2009.07.077. 
Raheleh, K., S. Ghassemi, and B. Asghari. 2019. Bio-fertilizer improves physio-biochemical characteristics and grain yield of safflower (Carthamus tinctorius L.) under drought stress. Russian Agricultural Sciences 45 (5):458-63. doi: $10.3103 /$ S1068367419050124.

Rezazadeh, H., S. K. Khorasani, and R. S. A. Haghighi. 2012. Effects of humic acid on decrease of phosphorus usage in forage maize var. KSC704 (Zea mays L.). Australian Journal of Agricultural Engineering 3 (2):34.

Rose, M. T., A. F. Patti, K. R. Little, A. L. Brown, W. Roy Jackson, and T. R. Cavagnaro. 2014. Chapter 2 - A meta-analysis and review of plant-growth response to humic substances: Practical implications for agriculture. In Advances in Agronomy, ed. D. L. Sparks, 37-89. Amsterdam, Netherlands: Academic Press.

Running, S. W., and R. R. Nemani. 1988. Relating seasonal patterns of the AVHRR vegetation index to simulated photosynthesis and transpiration of forests in different climates. Remote Sensing of Environment 24 (2):347-67.

Sahu, D., I. Priyadarshani, and B. Rath. 2012. Cyanobacteria-as potential biofertilizer. CIBTech Journal of Microbiology 1:20-6.

Sani, B. 2014. Foliar application of humic acid on plant height in canola. APCBEE Procedia 8:82-6. doi: 10.1016/j. apcbee.2014.03.005.

Sellers, P. J. 1987. Canopy reflectance, photosynthesis, and transpiration, II. The role of biophysics in the linearity of their interdependence. Remote Sensing of Environment 21 (2):143-83. doi: 10.1016/0034-4257(87)90051-4.

Senesi, N., and G. Brunetti. 1996. Chemical and physico-chemical parameters for quality evaluation of humic substances produced during composting. In The science of composting, eds. M. de Bertoldi, P. Sequi, B. Lemmes, and T. Papi, 195-212. Dordrecht: Springer Netherlands.

Shand, C. 2007. Plant nutrition for food security. A guide for Integrated Nutrient Management. Fertilizer and Plant Nutrition Bulletin 16:348.

Shirkhani, A., and S. Nasrolahzadeh. 2016. Vermicompost and Azotobacter as an ecological pathway to decrease chemical fertilizers in the maize, Zea mays. Bioscience Biotechnology Research Communications 9 (3):382-90. doi: $10.21786 / \mathrm{bbrc} / 9.3 / 7$.

Singh, V., Sharma, S. Kunal, S. K. Gosal, R. Choudhary, and R. Singh, Alok Adholeya, Bijay Singh. 2019. Synergistic use of plant growth-promoting Rhizobacteria, Arbuscular Mycorrhizal Fungi, and spectral properties for improving nutrient use efficiencies in wheat (Triticum aestivum L.). Communications in Soil Science and Plant Analysis, 51:1-14.

Singh, S., V. Singh, R. Datt Shukla, and K. Singh. 2018. Effect of fertilizer levels and Bio-fertilizer on green cob yield of corn (Zea mays L.). IJCS 6 (2):2188-90.

Snapp, S. S., P. L. Mafongoya, and S. Waddington. 1998. Organic matter technologies for integrated nutrient management in smallholder cropping systems of southern Africa. Agriculture, Ecosystems \& Environment 71 (1-3): 185-200. doi: 10.1016/S0167-8809(98)00140-6.

Sun, Q., W. Ding, Y. Yang, J. Sun, and Q. Ding. 2016. Humic acids derived from leonardite-affected growth and nutrient uptake of corn seedlings. Communications in Soil Science and Plant Analysis 47 (10):1275-82.

Theerawitaya, C., R. Tisarum, T. Samphumphung, C. Kirdmanee, and S. Cha-Um. 2017. Physio-morphological changes and fruit yield traits of Cavendish banana under organic farming management in the North region of Thailand. XIII International Symposium on Plant Bioregulators in Fruit Production 1206.

Tilman, D. 1998. The greening of the green revolution. Nature 396 (6708):211-2.

Tóth, V. R., I. Mészáros, S. Veres, and J. Nagy. 2002. Effects of the available nitrogen on the photosynthetic activity and xanthophyll cycle pool of maize in field. Journal of Plant Physiology 159 (6):627-34. doi: 10.1078/01761617-0640.

Varanini, Z., and R. Pinton. 1995. Humic substances and plant nutrition. In Progress in botany: Structural botany physiology genetics taxonomy geobotany/Fortschritte der Botanik Struktur Physiologie Genetik Systematik Geobotanik, eds. H. D. Behnke, U. Lüttge, K. Esser, J. W. Kadereit, and M. Runge, 97-117. Berlin, Heidelberg: Springer Berlin Heidelberg.

Vaughan, D. 1974. A possible mechanism for humic acid action on cell elongation in root segments of Pisum sativum under aseptic conditions. Soil Biology and Biochemistry 6 (4):241-7. doi: 10.1016/0038-0717(74)90058-3.

Vaughan, D., and R. E. Malcolm. 1985. Influence of humic substances on growth and physiological processes. In Soil organic matter and biological activity, 37-75. Switzerland: Springer.

Veres, S., L. Léva, I. Mészáros, and É. Gajdos. 2007. The effects of bio-fertilizers and nitrogen nutrition on the physiology of maize. Cereal Research Communications 35 (2):1297-300.

Vessey, J. K. 2003. Plant growth promoting rhizobacteria as biofertilizers. Plant and Soil 255 (2):571-86.

Viana, T. V. D. A., J. G. A. Lima, G. Gomes de Sousa, L. G. P. Neto, and B. M. d Azevedo. 2014. Growth, gas exchange and yield of corn when fertigated with bovine biofertilizer. Revista Caatinga 27 (3):106-14.

Vitousek, P. M., J. D. Aber, R. W. Howarth, G. E. Likens, P. A. Matson, D. W. Schindler, W. H. Schlesinger, and D. G. Tilman. 1997. Human alteration of the global nitrogen cycle: Sources and consequences. Ecological Applications 7 (3):737-50.[0737:HAOTGN]2.0.CO;2. doi: 10.1890/1051-0761(1997)007.[10.1890/10510761(1997)007[0737:HAOTGN]2.0.CO;2] 
Wang, R., K. Cherkauer, and L. Bowling. 2016. Corn response to climate stress detected with satellite-based NDVI time series. Remote Sensing 8 (4):269.

Weller, D. M. 2007. Pseudomonas biocontrol agents of soilborne pathogens: Looking back over 30 years. Phytopathology 97 (2):250-6. doi: 10.1094/phyto-97-2-0250.

Wu, S. C., Z. H. Cao, Z. G. Li, K. C. Cheung, and M. H. Wong. 2005. Effects of biofertilizer containing N-fixer, P and $\mathrm{K}$ solubilizers and AM fungi on maize growth: A greenhouse trial. Geoderma 125 (1-2):155-66. doi: 10. 1016/j.geoderma.2004.07.003.

Yildirim, E. 2007. Foliar and soil fertilization of humic acid affect productivity and quality of tomato. Acta Agriculturae Scandinavica, Section B - Plant Soil Science 57 (2):182-6.

Yosefi, K., M. Galavi, M. Ramrodi, and S. R. Mousavi. 2011. Effect of bio-phosphate and chemical phosphorus fertilizer accompanied with micronutrient foliar application on growth, yield and yield components of maize (Single Cross 704). Australian Journal of Crop Science 5 (2):175. doi: 10.5539/jas.v3n4p22.

Young, C.-C., P. D. Rekha, W.-A. Lai, and A. B. Arun. 2006. Encapsulation of plant growth-promoting bacteria in alginate beads enriched with humic acid. Biotechnology and Bioengineering 95 (1):76-83. doi: 10.1002/bit.20957.

Zarabi, M., Alahdadi, I. Gholam Abbas Akbari, and G. A. Akbari. 2011. A study on the effects of different biofertilizer combinations on yield, its components and growth indices of corn (Zea mays L.) under drought stress condition. African Journal of Agricultural Research 6 (3):681-5.

Zhang, X., E. H. Ervin, and R. E. Schmidt. 2003. Physiological effects of liquid applications of a seaweed extract and a humic acid on creeping bentgrass. Journal of the American Society for Horticultural Science 128 (4):492-6.

Zhang, X., R. E. Schmidt, E. H. Ervin, and S. Doak. 2002. Creeping bentgrass physiological responses to natural plant growth regulators and iron under two regimes. HortScience 37 (6):898-902. doi: 10.21273/HORTSCI.37.6. 898.

Zhang, R., and T. D. Sharkey. 2009. Photosynthetic electron transport and proton flux under moderate heat stress. Photosynthesis Research 100 (1):29-43. doi: 10.1007/s11120-009-9420-8.

Zhu, Y.-G., T. R. Cavagnaro, S. E. Smith, and S. Dickson. 2001. Backseat driving? Accessing phosphate beyond the rhizosphere-depletion zone. Trends in Plant Science 6 (5):194-5. doi: 10.1016/S1360-1385(01)01957-4.

Zhu, H., and D. Li. 2018. Using humus on golf course fairways to alleviate soil salinity problems. HortTechnology 28 (3):284-8. 